\title{
PENINGKATAN PEMBELAJARAN MENULIS KARANGAN NARASI MELALUI GAMBAR BERSERI SISWA SEKOLAH DASAR
}

\author{
Mohammad Siddik \\ Fakultas Ilmu Pendidikan, Universitas Mulawarman \\ Jalan Kuaro, P.O.B 1068, Samarinda, Kalimantan Timur \\ email: hmsiddik@yahoo.com
}

\begin{abstract}
The purpose of this study is to improve the narrative writing learning and evaluation using serial images. This study uses the classroom action research. The subject of this study is grade IV primary school by 36 students. The results showed significant increase on students' writing activity gradually. Evaluation of the process shows an increase in the effectiveness of the teachers' direction to the performed activity and students' ability. Evaluation of learning outcomes showed that cycle 1 reached good category (89\%) and cycle 2 reached very good category (96\%). It is recommended to principals for support the improvement of the writing narrative learning understanding and implementation on class.
\end{abstract}

Keywords: narrative writing, serial images, primary school.

\begin{abstract}
Abstrak: Tujuan penelitian ini adalah meningkatkan pembelajaran menulis karangan narasi dan evaluasi menggunakan gambar berseri. Penelitian ini menggunakan rancangan penelitian tindakan kelas. Subjek penelitian adalah siswa kelas IV berjumlah 36 siswa. Hasil penelitian menunjukkan adanya peningkatan yang signifikan dalam kegiatan menulis siswa secara bertahap. Evaluasi proses menunjukkan peningkatan efektivitas arahan guru terhadap aktivitas yang dilakukan dan kemampuan yang dikuasai siswa. Evaluasi hasil belajar siswa menunjukkan ada peningkatan pada siklus 1 mencapai kategori baik (89\%)dan siklus 2 mencapai kategori sangat baik (96\%). Disarankan kepala sekolah mendorong dan membina guru untuk berupaya meningkatkan pemahaman pembelajaran menulis karangan narasi dan pelaksanaannya di kelas.
\end{abstract}

Kata Kunci : menulis karangan narasi, gambar berseri, sekolah dasar

Penyelenggaraan pembelajaran dalam kurikulum bahasa tidak terlepas dari konsep cara pandang atau pendekatan terhadap linguistik. Pendekatan linguistik membawa pengaruh besar terhadap konsep dan pelaksanaan pembelajaran bahasa. Konsep dan pelaksanaan pembelajaran bahasa pada dasarnya dapat dibedakan atas pendekatan formal dan fungsional. Kurikulum pada mata pelajaran bahasa Indonesia dikembangkan berdasarkan pendekatan fungsional. Prinsip-prinsip pandangan fungsional melahirkan teori dasar yang digunakan dalam pembelajaran bahasa. Di dalam teori dasar pembelajaran bahasa dinyatakan bahwa belajar bahasa pada haki- katnya merupakan fakta sosial sebagai sarana untuk berkomunikasi (Richards \& Rodgers, 1986:45). Oleh karena itu, belajar bahasa adalah belajar berkomunikasi dalam berbagai interaksi sosial. Rafli \& Lustyantie (2016:9) menyatakan bahwa belajar komunikasi adalah suatu proses penyampaian maksud kepada orang lain yang dapat berupa pengungkapan pikiran, gagasan, ide, pendapat, dan lain-lain. Hal itu dapat diwujudkan dalam bentuk kebahasaan berupa kata, kalimat, paragraf, dan wacana.

Standar kompetensi mata pelajaran Bahasa Indonesia bersumber pada hakikat pembelajaran bahasa, yaitu belajar berkomunikasi. Standar kom- 
petensi mata pelajaran Bahasa Indonesia berfungsi untuk meningkatkan kompetensi berbahasa Indonesia secara nasional, meningkatkan kemampuan berpikir dan bernalar, serta meningkatkan daya intelektual. Standar kompetensi mata pelajaran Bahasa Indonesia di sekolah dasar (SD) bertujuan meningkatkan kemampuan siswa SD dalam berkomunikasi dengan baik secara lisan maupun tertulis (Depdiknas, 2006). Komunikasi lisan mencakup keterampilan menyimak dan berbicara, sedangkan komunikasi tertulis mencakup keterampilan membaca dan menulis. Keterampilan menulis sebagai salah satu keterampilan berbahasa merupakan suatu keterampilan yang harus dimiliki siswa SD agar mampu berkomunikasi secara tertulis.

Dewasa ini pendidikan di Indonesia, khususnya pendidikan dasar dan menengah menghadapi sejumlah masalah, seperti pencapaian nilai rata-rata hasil ujian akhir nasional sekolah dasar (SD), sekolah lanjutan tingkat pertama (SLTP), dan sekolah menengah umum (SMU) yang rendah untuk semua mata pelajaran, termasuk hasil pembelajaran bahasa Indonesia yang secara implisit mengajarkan pembelajaran menulis pada salah satu aspek keterampilan berbahasa di SD masih rendah. Rendahnya keterampilan menulis siswa SD menurut Tompkins dan Hoskisson (2010:141) tidak disebabkan oleh keterbatasan siswa tetapi disebabkan oleh pendekatan yang dipergunakan oleh guru yang tidak mengarahkan siswa agar dapat menulis dengan baik. Dalam pembelajaran bahasa Indonesia pendekatan rangkaian gambar dapat digunakan sebagai strategi untuk diimplementasikan ke dalam pembelajaran menulis narasi di SD.

Bentuk-bentuk tulisan dalam pembelajaran bahasa Indonesia, mencakup argumentasi, eksposisi, deskripsi, dan narasi. Dari keempat bentuk tulisan tersebut, tulisan narasi merupakan bentuk tulisan yang mampu membantu siswa mengatasi kesulitan yang berkaitan dengan pengalamannya. Menulis narasi merupakan kegiatan menulis bahasa bagaimana cara merangkai bahasa sebagai suatu karangan. Karangan berisi ide atau gagasan selengkaplengkapnya. Menurut MacMahan, Day, Funk, \& Coleman (2010) mengarang adalah menyusun buah pikiran yang melibatkan proses berbahasa. Pada pembelajaran menulis pengetahuan tetang proses mengarang harus dikuasai siswa agar dapat menulis dengan baik. Guru perlu melatih atau memberikan pengetahuan tentang mengarang narasi pada siswa sekolah dasar, agar siswa dapat mengembangkan isi hatinya ke dalam bentuk tulisan.

Pada saat menulis karangan, seringkali muncul beberapa permasalahan dalam merangkai kata menjadi kalimat, merangkai kalimat menjadi paragraf dan seterusnya sehingga menjadi sebuah karangan. Karangan merupakan hasil dari kegiatan mengarang yaitu perwujudan gagasan seseorang dalam bahasa tulis yang dapat dibaca dan dipahami orang lain (Karawasa, Sahrudin \& Budi, 2015) Untuk itulah kita harus mencari jalan keluarnya guna mengatasi ketidak mampuan siswa dalam mengarang. Tugas melatih karang mengarang itulah yang harus kita selesaikan. Tingkat sekolah dasar nantinya merupakan pengembangan untuk sekolah selanjutnya. Sesuai Peraturan Pemerintah Republik Indonesia Nomor 19 Tahun 20015 tentang Standar Nasional Pendidikan pasal 26 ayat (1) yang menyatakan bahwa pendidikan dasar bertujuan meletakan dasar, pada butir (6) disebutkan untuk mengikuti pendidikan lebih lanjut.

Ternyata setelah dilakukan pengamatan melalui studi pendahuluan hasil penilaian terhadap karangan narasi siswa kelas IV SD Negeri 006 Samarinda Ulu masih rendah tidak mencapai kriteria ketuntasan minimum (KKM). Hal itu, disebabkan kurangnya kesempatan siswa dalam mengemukakan isi hatinya yang dituangkan dalam bentuk tulisan. Akibatnya sering terjadi ketidaksesuaian antara isi karangan, bentuk gambar, pada karangan narasi. Oleh karena itu, hasil belajar siswa kelas IV SD Negeri 006 Samarinda Ulu tentang menulis narasi yang masih rendah itu perlu ditingkatkan.

Atas dasar permasalahan di atas itulah maka alternative pemecahannya perlu dirancang penelitian yang berjudul, "Peningkatan Pembelajaran Menulis Narasi Melalui Gambar Berseri pada Siswa Kelas IV Sekolah Dasar Negeri 006 Samarinda Ulu Tahun Pembelajaran 2016/2017". Penelitian ini secara umum menghasilkan temuan bagaimana peningkatan pembelajaran menulis narasi melalui gambar berseri siswa kelas IV SDN 006 Samarinda Ulu. Hasil penelitian peningkatan pembelajaran menulis narasi melalui gambar berseri pada siswa kelas IV SDN 006 Samarinda Ulu ini diwujudkan berdasarkan temuan pada peningkatan perencanaan, pelaksanaan, dan evaluasi pembelajaran. Dengan demikian, masalah masih rendahnya kualitas pembelajaran siswa dalam menulis narasi yang muncul dapat teratasi. 


\section{METODE}

Penelitian ini merupakan penelitian kualitatif menggunakan rancangan penelitian tindakan kelas yang dilaksanakan di SDN 006 Kecamatan Samarinda Ulu pada tahun pembelajaran 2016/2017 semester ganjil (1). Subyek penelitian adalah siswa kelas IV yang berjumlah 36 orang terdiri dari 15 orang siswa laki-laki dan 21 orang siswa perempuan. Rancangan penelitian ini sesuai dengan karakteristiknya, yaitu problem penelitian yang diangkat untuk dipecahkan selalu berangkat dari persoalan praktik pembelajaran sehari-hari yang dihadapi oleh guru di kelas Hopkins (dalam Djojosuroto, 2000). Oleh karena itu, guru akan dapat meningkatkan hasil pembelajaran jika guru tersebut mau melihat kembali pembelajaran yang telah diberikan kepada siswanya.

Kemmis dan MC Taggart (dalam Samsuddin, 2006:233) prosedur penelitian tindakan kelas ini dilakukakukan mulai dengan studi pendahuluan, (1) perencanaan, (2) pelaksanaan, (3) observasi, dan (4) refleksi. Kegiatan penelitian ini dimulai dari refleksi awal untuk melakukan kajian pendahuluan tentang kondisi objektif di lapangan. Langkah ini dilakukan untuk memperoleh informasi tentang kesulitan yang dialami oleh guru dan siswa serta dicarikan pemecahannya. Kemudian dilakukan kegiatan perencanaan, tindakan, observasi, dan analisis dan refleksi. Kegiatan pada setiap siklus dimungkinkan diikuti dengan perencanaan ulang, pelaksanaan ulang, observasi ulang, dan refleksi ulang. Namun, bila hasil yang diperoleh mengalami perubahan cenderung frekuensi persentasenya meningkat dibandingkan dengan siklus sebelumnya, maka pelaksanaan pada siklus berikutnya tidak perlu dilanjutkan, seperti tercermin pada keempat alur kegiatan penelitian yang berlangsung secara berdaur ulang dalam bentuk siklus. Pengumpulan data dan analisis data dalam penelitian ini dilakukan dengan teknik sebagai berikut. (1) pengamatan terhadap subyek dan obyek yang diteliti; (2) nilai rata-rata kelas pada tahun 2016/2017 tercatat masih belum memenuhi keriteria ketuntasan minimal (KKM) yang berlaku di SDN 006 Samarinda Ulu dan juga sebagai nilai dasar untuk digunakan sebagai acuan tes pada siklus I; (3) observasi, menggunakan tabel pedoman observasi untuk mengetahui tingkat aktivitas siswa pada saat pembelajaran; (4) teknik tes, tes terakhir siklus digunakan untuk mengetahui skor akhir siswa setiap siklusnya, tes ini dibuat oleh peneliti sesuai dengan materi yang diajarkan kepada siswa. Tes akhir siklus dan catatan observasi pada tahun pembelajaran 2016/2017 digunakan untuk mengetahui peningkatan motivasi siswa dan efektivitas pembelajaran menulis narasi melalui gambar berseri. Aspek yang diamati melalui pengamatan gambar berseri, meliputi: (1) kualitas gambar; (2) keefektifan penggunaan gambar; (3) penguasaan dalam penggunaan gambar; (4) pengaruh penggunaan gambar dalam pembelajaran. Hal ini dapat digunakan sebagai salah satu alat ukur prestasi belajar siswa.

\section{HASIL}

Berdasarkan hasil temuan mulai prasiklus, siklus 1, hingga siklus 2 tentang peningkatan pembelajaran menulis narasi melalui gambar berseri pada siswa kelas IV SDN 006 Samarinda Ulu dalam upaya meningkatkan kualitas pembelajaran kemampuan menulis dapat dilihat pada kemajuan hasil belajar siswa pada prasiklus dalam Tabel 1 .

Prasiklus dilakukan bertujuan untuk mengetahui keadaan awal keterampilan menulis narasi siswa. Data prasiklus digunakan untuk mengetahui letak kesulitan siswa dalam menulis narasi. Data prasiklus dianalisis untuk mendiagnosis masalah yang dialami siswa dalam menulis narasi. Agar peneliti dapat menentukan tindakan perbaikan pada

Tabel 1. Hasil Belajar Siswa dalam Pembelajaran Menulis Narasi pada Prasiklus

\begin{tabular}{clcccc}
\hline No & Kategori & Skor & Frekuensi & $\begin{array}{c}\text { Jumlah } \\
\text { Nilai }\end{array}$ & Presentase \\
\hline 1. & Sangat Baik & $90-100$ & 0 & 0 & 0 \\
2. & Baik & $80-89$ & 0 & 0 & 0 \\
3. & Cukup & $67-79$ & 13 & 982 & $36,1 \%$ \\
4. & Kurang & $0-66$ & 23 & 1323 & $63,9 \%$ \\
& Jumlah & \multicolumn{3}{c}{64,05} \\
\hline Rata-rata
\end{tabular}


siklus I dan siklus II. Tes yang dilaksanakan dalam prasiklus adalah tes esai. Jumlah siswa yang mengikuti tes prasiklus yaitu 36 siswa. Hasil rata-rata menulis narasi pada prasiklus hanya 64,08 Nilai rata-rata tersebut belum mencapai KKM SDN 006 Samarinda Ulu yakni 67. Nilai rata-rata siswa kelas IV dalam materi menulis narasi perlu ditingkatkan lagi. Karena, belum ada satu siswa pun yang memperoleh nilai dalam kategori baik dan sangat baik. Dengan demikian, data temuan hasil belajar siswa pada tahap prasiklus dapat dilihat pada Tabel 2 berikut.

Tabel 2. Data Hasil Belajar Siswa dalam Pembelajaran Menulis Narasi pada Prasiklus

\begin{tabular}{llcl}
\hline No & Kategori & Jumlah & Presentase \\
\hline 1. & Tuntas & 13 & $36,1 \%$ \\
2. & Belum Tuntas & 23 & $63,9 \%$ \\
\hline Jumlah & 36 & $100 \%$ \\
\hline
\end{tabular}

Berdasarkan data temuan hasil belajar tersebut sejumlah 36 siswa yang mengikuti tes prasiklus dalam menulis narasi, hanya 13 orang siswa masuk kategori cukup, sedangkan siswa yang termasuk kategori kurang berjumlah 23 orang siswa. Jadi, siswa yang memenuhi KKM sebesar (36.1\%) masuk kategori cukup, siswa yang belum memenuhi KKM sebesar $(63,9 \%)$ masuk kategori kurang.

Selanjutnya, hasil belajar pada siklus I dilakukan setelah tindakan dalam pembelajaran menulis narasi. Peneliti menilai hasil belajar berpedoman pada penilaian akhir karangan menggunakan unsur karangan. Aspek-aspek yang dinilai meliputi (1) isi gagasan yang dikemukakan, (2) organisasi isi, (3) tata bahasa, (4) gaya: pilihan struktur dan kosa kata, dan (5) ejaan. Kemajuan hasil belajar siswa pada siklus 1 dapat dilihat pada tabel 3.
Berdasarkan data temuan hasil belajar tersebut sejumlah 36 siswa yang mengikuti tes prasiklus dalam menulis narasi, hanya 13 orang siswa masuk kategori cukup, sedangkan siswa yang termasuk kategori kurang berjumlah 23 orang siswa. Jadi, siswa yang memenuhi KKM sebesar (36.1\%) masuk kategori cukup, siswa yang belum memenuhi KKM sebesar $(63,9 \%)$ masuk kategori kurang.

Selanjutnya, hasil belajar pada siklus I dilakukan setelah tindakan dalam pembelajaran menulis narasi. Peneliti menilai hasil belajar berpedoman pada penilaian akhir karangan menggunakan unsur karangan. Aspek-aspek yang dinilai meliputi (1) isi gagasan yang dikemukakan, (2) organisasi isi, (3) tata bahasa, (4) gaya: pilihan struktur dan kosa kata, dan (5) ejaan. Hasil belajar siswa dalam menulis narasi dapat diamati pada Tabel 3.

Pembelajaran kegiatan siklus 1 siswa diarahkan untuk mengamati gambar yang di bentang di depan kelas, para siswa di harapkan memperoleh konsep tentang topik tertentu. Selanjutnya, pada tahap pramenulis dengan menentukan urutan gambar sesuai seri. Urutan gambar sebagai dasar dalam penjabaran tema menjadi beberapa topik. Mengembangkan topik dan penentuan judul disesuaikan dengan maksud gambar berseri. Sedangkan penyusunan kerangka karangan berdasarkan rangkaian gambar seri.

Pada tahap pelaksanaan difokuskan pada kualitas gambar untuk menuangkan gagasan menjadi draf menulis narasi. Kemudian dilakukan perevisian dan perbaikan untuk mengetahui penguasaan dalam penggunaan gambar. Setelah itu, dilakukan penyuntingan atau pengeditan menentukan keefektifan penggunaan gambar. Pada tahap pascamenulis bagian akhir dari kegiatan menulis narasi ini difokuskan dengan mempublikasikan tulisan. Siswa secara bergiliran membacakan tulisannya di depan kelas untuk melihat pengaruh penggunaan gambar dalam pembelajaran menulis narasi.

Tabel 3. Hasil Belajar Siswa dalam Pembelajaran Menulis Narasi pada Siklus 1

\begin{tabular}{llcc}
\hline No & \multicolumn{1}{c}{ Aspek yang Dinilai } & $\begin{array}{c}\text { Parameter } \\
\text { Skor }\end{array}$ & $\begin{array}{c}\text { Hasil Belajar } \\
\text { (Skor/Konversi Nilai/Frekuensi) }\end{array}$ \\
\hline 1 & Isi Gagasan yang Dikemukakan & $05-25$ & $24 / 96 / 14 ; 23 / 92 / 17 ; 21 / 84 / 5$ \\
2 & Organisasi Isi & $05-25$ & $23 / 92 / 15 ; 22 / 88 / 18 ; 21 / 84 / 3$ \\
& \multirow{2}{*}{3} & $05-25$ & $20 / 80 / 16 ; 19 / 76 / 18 ; 18 / 72 / 2$ \\
Tata bahasa & & & \\
4 & Gaya: Pilihan Struktur dan Kosa Kata & $08-20$ & $18 / 90 / 24 ; 17 / 85 / 8 ; 16 / 80 / 4$ \\
5 & Ejaan & $02-05$ & $05 / 100 / 28 ; 04 / 80 / 8 ;$ \\
\hline
\end{tabular}


Berdasarkan hasil belajar siswa dalam pembelajaran menulis narasi pada siklus 1 rata-rata nilai yang diperoleh siswa sebesar $(89 \%)$. Peneliti mengkategorikan hasil belajar siswa berpedoman pada penilaian akhir karangan dan indikator keberhasilan. Parameter penilaian kualitatif berdasarkan presentase kemampuan siswa, meliputi: (1) 86-100 Tinggi Sekali (Sangat Baik); (2) 66-85 Tinggi (Baik); (3) 46-65 Cukup; (4) 26-45 Rendah (Kurang); (5) 0-25 Rendah Sekali (Kurang Sekali) dimodifikasi dari (sumber buku rapot siswa Depdiknas, 1993). Hasil belajar yang dicapai siswa dalam pembelajaran menulis narasi lebih besar (22\%) dibandingkan dengan KKM yang ditentukan oleh SDN 006 Samarinda Ulu. Dengan demikian, data temuan hasil belajar siswa dalam pembelajaran menulis narasi pada tahap siklus 1 dapat dilihat pada Tabel 4.

Berdasarkan perbaikan yang dilakukan, maka data temuan hasil belajar tersebut sejumlah 36 siswa yang dikenakan sebagai subjek belajar dinyatakan tuntas. Nilai yang diperoleh siswa ratarata di atas ketentuan KKM yang ditetapkan di sekolah. Namun demikian, KKM yang ditentukan di sekolah hanya masuk pada kategori baik. Nilai KKM yang ditetapkan SDN 006 Samarinda Ulu tersebut dikhawatirkan kalah bersaing dengan sekolah-sekolah lain yang menetapkan nilai KKM yang lebih tinggi dari nilai (67). Pada akhir tindakan siklus 1, dilakukan diskusi dengan guru mengenai hasil karya tulisan siswa berdasarkan hasil analisis dirumuskan tindak lanjut pada siklus berikutnya, yakni siklus 2 yang pelaksaannya sama dengan siklus 1. Kemajuan hasil belajar siswa pada siklus 2 dapat dilihat pada tabel 5 .

Pembelajaran kegiatan siklus 2 siswa diarahkan untuk mengamati gambar yang dibentang di depan kelas sebagaimana pelaksanaan kegiatan pada siklus 1. Penggunaan media gambar ini berfungsi memaksimalkan pembelajaran sehingga dapat menulis karangan narasi berdasarkan gambar-gambar simbol berseri. Media gambar ini juga dimanfaatkan untuk menciptakan suasana belajar yang menarik sehingga aktivitas belajar siswa meningkat. Adapun proses pembelajaran menulis pada siklus 2 sebagaimana pelaksanaan pada siklus 1 dimulai dengan tahap pramenulis yang difokuskan pada penjabaran tema, pemilihan topik, mengembangkan topik, penentuan judul, penyusunan kerangka karangan. Sedangkan pada tahap pelaksanaan difokuskan pada menuangkan gagasan menjadi draf menulis narasi. Kemudian dilakukan perevisian dan perbaikan. Setelah itu, dilakukan penyuntingan atau pengeditan. Pada tahap pascamenulis bagian akhir dari kegiatan menulis narasi ini difokuskan dengan mempublikasikan tulisan secara bergiliran beberapa siswa membacakan di depan kelas. Dengan demikian, data temuan hasil belajar siswa dalam pembelajaran menulis narasi pada tahap siklus 2 dapat dilihat pada Tabel 6 .

Berdasarkan hasil belajar siswa dalam pembelajaran menulis narasi pada siklus 2 rata-rata nilai yang diperoleh siswa sebesar (96\%). Artinya, hasil belajar yang dicapai siswa meningkat (7\%) dari pada siklus 1. Jika dibandingkan dengan KKM yang ditentukan oleh SDN 006 Samarinda Ulu, hasil belajar pada siklus 2 ini meningkat secara signifikan. Peningkatan hasil belajar mencapai (29\%). Oleh karena itu, pada akhir tindakan siklus 2, dilakukan diskusi dengan guru mengenai hasil karya tulisan siswa. Berdasarkan hasil analisis tersebut disepakati tidak perlu dilanjutkan pada siklus berikutnya (siklus 3), dengan pertimbangan bahwa hasil belajar siswa menunjukkan peningkatan yang signifikan dibanding dengan siklus 1 .

Tabel 4. Data Hasil Belajar Siswa dalam Pembelajaran Menulis Narasi pada siklus 1

\begin{tabular}{|c|c|c|c|c|c|}
\hline No & Aspek yang Dinilai & Frekuensi & $\begin{array}{c}\text { Rata-rata Aspek } \\
\text { yang Nilai (\%) }\end{array}$ & Kategori & Keterangan \\
\hline 1. & Isi Gagasan yang dikemukakan & 36 & 92 & Sangat Baik & Tuntas \\
\hline 2. & Organisasi Isi & 36 & 89 & Baik & Tuntas \\
\hline 3 & Tata bahasa & 36 & 78 & Cukup & Tuntas \\
\hline 4 & Gaya: Pilihan Struktur dan Kosa Kata & 36 & 88 & Baik & Tuntas \\
\hline \multirow[t]{3}{*}{5} & Ejaan & 36 & 96 & Sangat Baik & Tuntas \\
\hline & Jumlah Nilai & & 443 & & \\
\hline & Rata-rata Nilai secara Keseluruhan & & 89 & Baik & Tuntas \\
\hline
\end{tabular}


Tabel 5. Hasil Belajar Siswa dalam Pembelajaran Menulis Narasi pada Siklus 2

\begin{tabular}{clcl}
\hline No & \multicolumn{1}{c}{ Aspek yang Dinilai } & Parameter Skor & \multicolumn{1}{c}{ Hasil Belajar } \\
\hline 1 & Isi gagasan yang dikemukakan & $05-25$ & $24 / 96 / 18 ; 23 / 92 / 18$ \\
2 & Organisasi Isi & $05-25$ & $24 / 96 / 19 ; 23 / 92 / 17 ;$ \\
3 & Tata Bahasa & $05-25$ & $24 / 96 / 14 ; 23 / 92 / 18 ; 22 / 88 / 4$ \\
4 & Gaya: Pilihan Struktur dan Kosakata & $08-20$ & $20 / 100 / 24 ; 19 / 95 / 10 ; 18 / 90 / 2$ \\
5 & Ejaan & $02-05$ & $05 / 100 / 36$ \\
\hline
\end{tabular}

Tabel 6. Data Hasil Belajar Siswa dalam pembelajaran Menulis Narasi pada siklus 2

\begin{tabular}{llcccc}
\hline No & Aspek yang Dinilai & $\begin{array}{c}\text { Frekue- } \\
\text { nsi }\end{array}$ & $\begin{array}{c}\text { Rata-rata } \\
\text { Aspek yang } \\
\text { Nilai (\%) }\end{array}$ & Kategori & \\
\hline 1 & Isi Gagasan yang Dikemukakan & 36 & 94 & Sangat Baik & Tuntas \\
2 & Organisasi Isi & 36 & 94 & Sangat Baik & Tuntas \\
3 & Tata bahasa & 36 & 93 & Sangat Baik & Tuntas \\
$4 \quad$ Gaya: Pilihan Struktur dan Kosa Kata & 36 & 98 & Sangat Baik & Tuntas \\
5 & Ejaan & 36 & 100 & Sangat Baik & Tuntas \\
Jumlah Nilai & & 479 & & \\
\hline Rata-rata Nilai secara Keseluruhan & & $\mathbf{9 6}$ & Sangat Baik & Tuntas \\
\hline
\end{tabular}

\section{PEMBAHASAN}

Pembahasan yang melandasi penelitian ini adalah data dan temuan pada dua siklus aktivitas siswa dalam pembelajaran menulis narasi melalui gambar berseri. Kegiatan pada tahap pramenulis dengan menentukan urutan gambar sesuai seri. Urutan gambar sebagai dasar dalam penjabaran tema menjadi beberapa topik. Mengembangkan topik dan penentuan judul disesuaikan dengan maksud gambar berseri. Sedangkan penyusunan kerangka karangan berdasarkan rangkaian gambar seri. Hasil temuan yang berkaitan dengan pemilihan tema pada setiap siklus hanya dibahas satu tema. Pada siklus 1 tema yang dipilih adalah indahnya kebersamaan. Pada siklus 2 tema yang dipilih adalah selalu berhemat energi. Tema indahnya kebersamaan dan selalu berhemat energi bersumber pada muatan kurikulum tingkat satuan pendidikan (Depdikbud, 2006).

Kedua tema yang dipilih baik pada siklus 1 maupun siklus 2 dikembangkan menjadi subtema. Hasil temuan yang berkaitan dengan penentuan subtema pada setiap siklus. Subtema pengalaman liburan pada siklus 1 dan subtema hemat pangkal kaya pada siklus 2 ditentukan melalui curah pendapat. Guru memberikan kesempatan kepada siswa untuk memilih sendiri subtema melalui curah pendapat sesuai dengan minat dan pengetahuannya. Haryadi \& Zamzami (1996:42) menyatakan bahwa agar tidak terlalu sulit melakukan evaluasi ada baiknya apabila tema, judul, jumlah kata ditentukan oleh guru. Guru dimungkinkan untuk mengembangkan tema menjadi subtema yang disesuaikan dengan usia, minat, keadaan dan kebutuhan setempat serta pengetahuannya. Artinya, pembelajaran bahasa Indonesia dapat dikembangkan melalui tematik.

Pengembangan topik dilakukan dengan berbagai teknik. Salah satu teknik yang digunakan guru ialah menyusun pertanyaan. Hasil temuan yang berkaitan dengan penentuan pengembangan topik pada setiap siklus. Pengembangan topik dengan teknik menyusun pertanyaan menunjukkan siswa dapat melakukan hal itu dengan strategi curah pendapat. Tarigan (1986:65) mengemukakan aneka teknik pengajaran menulis, salah satunya melalui menjawab pertanyaan. Latihan menjawab pertanyaan bagi siswa dapat menumbuhkan keterampilan menyusun karangan yang terarah. Selanjutnya, Routman (1994:220) menyatakan bahwa dalam proses penyusunan pertanyaan dan jawaban, siswa perlu memperoleh bimbingan dari guru. Sejalan dengan hal itu, Tompkins \& Hoskisson (2010) menyatakan bahwa dalam proses pengembangan dan pemilihan topik, guru dapat membantu siswa melalui curah pendapat untuk menggali dan memperoleh sejumlah topik yang sesuai tema dan memilih salah satu topik yang paling diminatinya. Burns, Roeb, 
\& Ross (2008:132) menyatakan bahwa proses penyusunan pertanyaan dan jawaban sebelum menulis draf memberi kesempatan bagi siswa berpikir tentang apa yang akan ditulis. Dengan demikian, jawaban pertanyaan yang benar bila disatukan dapat membantu siswa dalam menyusun suatu karangan yang baik.

Hasil temuan yang berkaitan dengan kegiatan penyusunan kerangka karangan menunjukan bahwa semua siswa terteliti mampu mengembangkan rincian dari butir pertanyaan dan jawaban menjadi kerangka karangan. Guru menggunakan demontrasi untuk memberikan strategi pemodelan dengan menyusun pertanyaan dan jawaban. Demonstrasi merupakan salah satu bentuk bimbingan guru agar siswa dapat menulis dengan baik sebagaimana hasil penelitian Suay \& Chervona (2011) bahwa bimbingan guru berpengaruh positif terhadap kemampuan belajar siswa. Kerangka karangan disusun berdasarkan butir jawaban dari pertanyaan yang berisi gagasan pokok atau kalimat topik dan beberapa gagasan penunjang. Pada pelaksanaan pembelajaran tahap menulis, semua siswa terteliti telah mampu: (1) menuangkan gagasan menjadi draf karangan narasi, (2) melakukan perevisian atau perbaikan karangan narasi, (3) melakukan penyuntingan atau pengeditan karangan narasi, (4) penulisan kembali hasil perevisian draf karangan narasi.

Hasil temuan yang berkaitan dengan pembelajaran pengedrafan, yaitu menuangkan gagasan menjadi draf awal karangan narasi menunjukkan bahwa semua siswa mampu melakukan pengembangannya berdasar pada kerangka karangan yang telah disusun pada tahap pramenulis. Hal ini sesuai dengan hasil penelitian Susanti (2013) bahwa penggunaan media gambar berseri dapat meningkatkan keteranpilan menulis narasi siswa kelas IV SDN Tambak Kemeraan Kecamatan Krian. Proses pengedrafan dengan mengembangkan kerangka karangan disusun siswa mengacu pada penalaran deduktif dan induktif dengan pola kronologis menjadi karangan yang utuh, topik dikembangkan melalui strategi pemodelan, kalimat pembuka ditulis melalui strategi tanya jawab dan konferen guru-siswa, strategi konferensi guru-siswa untuk pengedrafan sesuai kriteria karangan.

Guru mengarahkan siswa untuk menulis karangan narasi dengan penalaran deduktif dan induktif, karena disesuaikan dengan muatan kurikulum. Penalaran deduktif dan induktif dalam bahan bacaan teks bersifat situasional yan berarti teks mengacu kepada hal-hal yang merujuk kepada di luar teks itu sendiri, seperti latar belakang peristiwa atau latar belakang pengarang (Izhar, 2016). Tugas yang diberikan kepada siswa untuk dikerjakan hanya berkaitan dengan penalaran deduktif. Selanjutnya, temuan penulisan pengedrafan karangan narasi yang berkaitan dengan strategi pemodelan menunjukkan bahwa siswa mampu melakukan pengembangan dimulai dari suatu topik. Topik tersebut dibagi menjadi kalimat topik atau sebagai gagasan pokok kemudian beberapa kalimat penunjang. Topik dikembangkan melalui strategi pemodelan dengan penalaran deduktif dan induktif. Selain itu media gambar digunakan untuk mempermudah siswa dalam menentukan situasi kronolgi cerita. Bantuan ini digunakan karena siswa lebih menyukai gambar daripada tulisan, apalagi jika gambar dibuat dan disajikan sesuai dengan persyaratan yang baik (Juldianty, 2016)

Strategi pemodelan ini hanya diberikan guru pada siklus 1, setelah siswa mendapatkan pemahaman tentang menulis karangan narasi dengan penalaran deduktif dan induktif pada siklus 2 tidak diberikan. Jadi, strategi pemodelan hanya berfungsi untuk mengantarkan siswa memahami struktur karangan narasi kaitannya dengan teori yang dipelajarinya. Adapun temuan penulisan pengedrafan karangan narasi yang berkaitan dengan teknik tanya jawab masih belum mampu mendorong siswa untuk memulai menulis. Aktivitas tersebut dilakukan guru pada siklus 1 . Pada siklus 2 guru melakukan aktivitas bervariatif yaitu melalui strategi konferen guru-siswa. Strategi konferen guru-siswa digunakan guru untuk membantu menuliskan kalimat pembuka sebagai pancingan, yang kemudian dilanjutkan oleh siswa yang bersangkutan. Aktivitas guru tersebut nampak ketika membantu siswa terteliti dalam pengedrafan karangan yang baik dan efektif. Hal itu, nampak pada hasil kerja siswa, yang memaksimalkan penggunaan media gambar berseri dalam setiap karangan narasi yang ditulis, sehingga karangan narasi ditulis berdasarkan gambar-gambar simbol berseri. Selain itu kegiatan guru juga melakukan pengajuan pertanyaan melalui pertanyaan 5W 1H menurut Misrah \& Effendi (2015) menjelaskan 5W $1 \mathrm{H}$ merupakan kalimat tanya untuk penggalian informasi untuk memperoleh cerita.

Teknik yang digunakan siswa dalam menulis karangan narasi adalah pola kronologi yang berkaitan 
dengan suatu peristiwa dan kejadian. Akhadiah, Maida, \& Sakura (1989:38) menyatakan bahwa karangan narasi terdapat tiga unsur utama, yakni (1) tokoh tokoh, (2) kejadian, dan (3) latar atau ruang dan waktu. Karangan narasi terbagi menjadi dua jenis, yakni: (1) narasi fiksi, dan (2) narasi nonfiksi. Narasi fiksi adalah mengisahkan peristiwaperistiwa imajinatif. Narasi fiksi ini disebut juga narasi sugestif, seperti novel, roman, dan cerpen. Narasi nonfiksi adalah narasi yang mengisahkan peristiwa faktual, sesuatu yang ada dan benarbenar terjadi. Narasi ini disebut juga narasi ekspositoris, seperti biografi dan laporan perjalanan (Lubis, 2014). Namun demikian, temuan yang berkaitan dengan penelitian ini, terdapat pada hasil kerja siswa hanya menggunakan teknik narasi fiksi berupa suatu peristiwa dan kejadian sesuai tugas yang diberikan oleh gurunya.

Berdasarkan hasil temuan dalam penelitian ini secara umum tindakan yang dilakukan terhadap penulisan karangan narasi semua siswa terteliti mampu menerapkan unsur karangan narasi. Namun, ada beberapa siswa hasil karangannya tidak mengikuti penerapan unsur karangan narasi yang justeru cenderung tidak mengikuti pola jenis karangan tertentu. Diduga kelemahan tersebut diakibatkan proses belajar mengajar tidak menggunakan pendekatan yang sesuai dengan bakat dan minat siswa. Penyampaian materi pengajaran tidak menggunakan strategi pembelajaran yang tepat. Dengan demikian, temuan strategi pemodelan dapat membantu siswa menulis karangan narasi sesuai kriterianya, yaitu adanya tokoh, adanya kejadian, dan adanya latar atau ruang serta waktu berdasarkan gambar-gambar simbol berseri. Penggunaan srategi ini sesuai dengan hasil penelitian sebelumnya oleh Darmani, Marhaeni, \& Sutama (2013) bahwa strategi pemodelan dapat meningkatkan kemampuan menulis siswa berdasarkan bakat verbal. Perbaikan dilakukan guru melalui proses pembelajaran yang berulang-ulang. Diharapkan siswa memperoleh pengalaman dari aktivitas tersebut. Menulis merupakan suatu proses penuangan gagasan secara tertulis ke dalam draf sementara yang perlu diproses ulang atau diperbaiki. Perbaikan itu berupa mengganti, menghilangkan, menambah, menyusun ulang kata/frase, kalimat, atau paragraf dengan menggunakan strategi kesejawatan / sharing antar siswa.

Guru melakukan perevisian atau perbaikan untuk mengetahui sejauhmana kemampuan siswa menulis karangan narasi memenuhi kriteria ka- rangan narasi yang baik, dan sejauhmana siswa mampu menempatkan unsur narasi dalam menulis karangan secara tepat. Berdasar pada temuan hasil revisi yang berkaitan dengan penggunaan kriteria karangan, siswa mampu memenuhi kriteria karangan yang baik. Setiap karangan yang ditulis siswa memiliki kelengkapan unsur karangan narasi artinya setiap karangan yang ditulis siswa memuat tokoh, kejadian, latar, ruang, dan waktu, sehingga pembaca dapat mengikuti pikiran yang terkandung dalam karangan tersebut dengan mudah. Temuan yang berkaitan dengan hasil pembelajaran penyuntingan melalui aktivitas sharing diketahui bahwa siswa sudah dapat melakukan penyuntingan atau pengeditan terhadap aspek mekanikal tulisan seperti penulisan huruf besar, penulisan tanda baca, penulisan pemenggalan kata diakhir baris, dan pilihan kata. Proses penyuntingan berlangsung responsif, siswa merasa senang dapat menyunting hasil pekerjaan temannya, begitu pula sebaliknya, siswa merasa senang menerima masukkan dari temannya.

Berdasar pada temuan hasil penyuntingan atau pengeditan melalui kesejawatan yang berkaitan dengan penulisan huruf kapital, pilihan kata (diksi), dan mekanikal lainnya, siswa mampu menempatkan atau melakukan sesuai dengan pedoman umum ejaan yang berlaku. Misalnya semua siswa terteliti menempatkan huruf kapital menjadi judul tulisan karangan narasi. Strategi kesejawatan dengan pola pemberian kemudahan dapat dilaksanakan dengan baik dan fungsional. Hal tersebut disebabkan pola pemberian kemudahan mempunyai serangkaian petunjuk atau pertanyaan yang dapat menuntun dan memudahkan siswa untuk memperbaiki draf awal karangan temannya atau karangannya sendiri. Temuan tersebut sejalan dengan Ellis, Standal, Pennau, \& Rumel (1989:19) bahwa cara efektif yang dapat membantu penulis untuk mengembangkan dan meningkatkan keterampilan menulisnya adalah dengan mengadakan temu pendapat dengan teman sejawat. Dengan demikian, siswa akan memperoleh dampak pengiring melalui pembelajaran penyuntingan. Pada data awal penelitian ini sikap tersebut belum tampak, karena siswa tidak memperoleh kesempatan untuk menyunting tulisan.

Pelaksanaan pembelajaran tahap pascamenulis, masing-masing kelompok mewakilkan salah seorang dari anggota kelompoknya sebagai siswa terteliti, ternyata mampu : (1) membaca tulisan karangan narasi di depan kelas dengan lafal dan 
intonasi yang wajar, kejelasan suara, kelancaran membaca, (2) menuliskan kembali tulisan hasil diskusi kelas, (3) memajankan hasil tulisan karangan narasi pada tempat papan pemajanan. Temuan yang berkaitan dengan pembelajaran pemublikasian, semua siswa terteliti sudah dapat membaca tulisan karangan narasi di depan kelas dengan lafal dan intonasi yang wajar, kejelasan suara yang memadai, dan kelancaran membaca yang baik. Dengan demikian, selama pelaksanaan membaca sekalipun temuan secara umum dinyatakan baik. Namun, ditemukan beberapa kesalahan yang jumlahnya relative sedikit di siklus 1 yang kemudian dilakukan perbaikan, hal ini dikarenakan sebelum memberikan tugas kepada siswa untuk membaca di depan kelas terlebih dahulu diberikan contoh membaca oleh gurunya pada siklus 1 , sedangkan pada kegiatan siklus 2 sudah tidak perlu diberikan contoh lagi

\section{SIMPULAN DAN SARAN}

\section{Simpulan}

Berdasarkan hasil penelitian dan pembahasan dapat disimpulkan sebagai berikut; Pelaksanaan pada tahap menulis kegiatan yang dilakukan adalah: Pertama, menuangkan gagasan menjadi draf karangan narasi, melakukan perevisian atau perbaikan karangan narasi, melakukan penyuntingan atau pengeditan karangan narasi. Kedua, prosedur untuk menuangkan gagasan ke draf tulisan karangan narasi menggunakan strategi konferen siswa-guru. Ketiga, prosedur untuk melaksanakan perevisian draf karangan narasi menggunakan strategi curah pendapat. Keempat, prosedur penyuntingan draf karangan narasi menggunakan kesejawatan siswa dalam bentuk sharing. Kelima, hasil yang diperoleh siswa pada kegiatan menulis menunjukkan peningkatan yang signifikan dalam aktivitas pengedrafan, perevisian, dan penyuntingan.

\section{Saran}

Pertama, disarankan kepada guru SD hendaknya memperluas penerapan konsep hasil penelitian tersebut di kelas, agar dapat mendorong peningkatan keterampilan menulis siswa di SD. Kedua, disarankan kepada Kepala SD hendaknya mendorong dan melakukan pembinaan kepada guru agar selalu berupaya meningkatkan pemahamannya tentang pembelajaran menulis karangan narasi dengan strategi yang berdasar pada pendekatan proses menulis. Ketiga, disarankan kepada LPTK (Lembaga Pendidikan dan Tenaga Kependidikan) S1 PGSD yang menangani masalah ke-SD-an agar secara terus menerus menyelenggarakan seminar atau lokakarya berkaitan dengan pembelajaran menulis karangan narasi berdasarkan pada pendekatan proses menulis. Keempat, disarankan kepada para peneliti agar penelitian ini dapat dijadikan salah satu sumber rujukan untuk menindaklanjuti penelitian tindakan serupa.

\section{DAFTAR RUJUKAN}

Akhadiah,S.,Maidar,G.A., \& Sakura, H.R. 1989. Pembinaan kemampuan Menulis Bahasa Indonesia, Jakarta : Erlangga.

Burns, P.C.,RoeB.D., \& Ross,E.P. 2008. Teaching Reading in today's Elementary School. Boston: Houghton Mifflin.

Suay, H.B., \& Chervona, H. 2011. Effect of Human Guidance and State Space Size on Interactive Reinforcement Learning. Artikel disajikan pada IEEE Explore Atlanta USA. DOI: https://doi. org/10.1109/ROMAN.2011.6005223, 31 Jui-3 Agustus 2011.

Darmani, N.N., Marhaeni, A.A.I.N., \& Sutama, I. M. 2013. Pengaruh Strategi Pemodelan Berbantuan Media Cetak Terhadap Kemampuan Mengarang Prosa Siswa Kelas V SD Ditinjau Dari Bakat Verbal. Jurnal Pendididkan Dasar Pascasarjana Universitas Pendidikan Ganesha, 2(1).

Depdiknas. 2006. Kurikulum Tingkat Satuan Pendidikan (KTSP) untuk Sekolah Dasar/MI. Jakarta: Terbitan Depdiknas.

Ellis, A., Standal, T., Pennau, J., \& Rummel, M.K. 1989. Elementary Languange Arts Instruction. Englewood Cliffs, New Jersey : Prentice Hall.

Haryadi., \& Zamzani. 1996. Peningkatan Keterampilan Berbahasa Indonesia, Jakarta : Depdikbud-Dikti.

Izhar. 2016. Mengidentifikasi Cara Berpikir Deduktif dan Induktif dalam Teks Bacaan Melalui Pengetahuan Koteks dan Referensi Pragmatik. Jurnal Pesona, 2 (1), $63^{-} 73$.

Juldianty. Peningkatan Keterampilan Menulis Narasi Melalui Penggunaan Media Gambar Seri Siswa kelas III. Jurnal Pendidikan Dasar, 7 (2).

Karawasa, Hani., Sahrudin., \& Budi. 2015. Meningkatkan Kemampuan Menulis Karangan 
Sedeerhana Siswa Kelas IV SDN Mire Melalui Penggunaan Media Gambar Seri. Jurnal Kreatif Tadukalo, 5 (2), 1-10.

Lubis, R.F. 2014. Writing Narrative Text . Journal of English Education, 2 (01),

MacMahan, E., Day, S.E., Funk, R., \& Coleman, L. 2010. Literature and Writing Process. New York: Pratice Hall PTR.

Misrah, Saharudin., \& Efendi. 2015. Peningkatan siswa membuat kalimat tanya melalui Teknik 5W 1H dikelas IV SD Lobu Gio. Jurnal Kreatif Tadukalo, 1 (4), 55-66.

Poerwadarminta, W.J.S. 1979. Bahasa Indonesia Untuk Karang-Mengarang: Petunjuk Menggunakan Bahasa Indonesia Secara Tepat Praktis. Yogyakarta: U.P Indonesia.

Rafli, Z., \& Lustyantie, N. 2016. Teori Pembelajaran Bahasa (Suata Catatan Singkat). Yogyakarta: Garudhawaca.

Richards., \& Rodgers.1986. Approaches and Methods in Language Teaching. United States: Cambridge University Press.
Routman, R. 1994. Invitations : Changing as Teacher and Learner K-12. Toronto : Irwin Publishing.

Susanti, Apriliya. 2013. Penggunaan Media Gambar Berseri Untuk Meningkatkan Keterampilan

Menulis Narasi Siswa Kelas IV SDN Tambak Kemeraan Kecamatan Krian. Jurnal Penelitian Pendidikan Guru Sekolah Dasar, 1 (2). Dari http:// Jurnalmahasiswa.Unesa.Ac.Id/Index.Php/ Jurnal-Penelitian-Pgsd/Article/View/2933, dikases pada 20 November 2016.

Tarigan, D. 1986. Membina Keterampilan : Menulis Paragraf Dan Pengembangan. Bandung : Angkasa.

Tompkins, G.E., \& Hoskisson, K. 2010. Languange Art Ciontent and Teaching Strategies. New York : Macmillan. 